\title{
THE URGENCY OF ROME STATUTE OF THE INTERNATIONAL CRIMINAL COURT RATIFICATION FOR REPUBLIC OF INDONESIA
}

\author{
Yordan Gunawan* \& Resa Wilianti**
}

\begin{abstract}
Rome Statute of the International Criminal Court has been agreed on July 15, 1998 and even though the Statute has entered into force 12 years ago, many democratic nations have not signed or ratified it. This includes Indonesia, along with United States of America, Russia, and other countries. In terms of human rights protection, since year 2000 Indonesia has enacted Law No. 26 of 2000 on Human Rights Court. However, it has not sufficiently upheld human rights enforcement. The National Action Plan for Human Rights of Indonesia in 2004-2009 stated that the government expects to ratify the Rome Statute in 2008. Truthfully, the target has not been realized, thus in 2009-2014 the government pursues to ratify the Rome Statute in 2013. Indonesia encouraged ratifying the Rome Statute of the International Criminal Court in the legislation since there are several serious crimes committed, but the law enforcement is unable to investigate exhaustively. Based on the Statute, the court will take the cases from the country, which is unwilling and unable to investigate the case of human rights, if the state already ratifies the Statute. The type of this research is a normative legal research with Statute Approach and Case Approach. By using a qualitative descriptive method, this research will describe the Rome Statute of the International Criminal Court ratification in details related to regulations and conventions especially that related to the Rome Statute of the International Criminal Court. Finally, the result shows the reason why the ratification of Rome Statute of the International Criminal Court for Republic of Indonesia is very urgent and important.
\end{abstract}

INTRODUCTION

I. IMPLEMENTATION OF ROME STATUTE OF THE INTERNATIONAL CRIMINAL COURT TOWARDS REPUBLIC OF INDONESIA ........................................... 25

A. Overview of the History of Indonesia: East Timor Tribunal...... 25

$B$. Indonesia's Role in the Establishment of the International

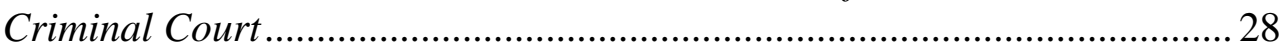

C. The Process of Indonesia in Ratifying the Rome Statute............ 29

D. A Brief Comparison Between Rome Statute of the International Criminal Court and Indonesian Criminal Procedure Code ..........................30

\footnotetext{
* Yordan Gunawan, International Program for Law and Sharia (IPOLS), Faculty of Law, Universitas Muhammadiyah Yogyakarta, Indonesia. Research fields: International Law.

${ }^{* *}$ Resa Wilianti, International Program for Law and Sharia (IPOLS), Faculty of Law, Universitas Muhammadiyah Yogyakarta, Indonesia. Research fields: International Law.
} 
II. THE IMPORTANCE OF THE RATIFICATION OF THE RoME STATUTE ..............36

A. Important Steps on Rome Statute of the ICC Ratification ............38

B. $\quad$ Recommended Measures ..........................................................40

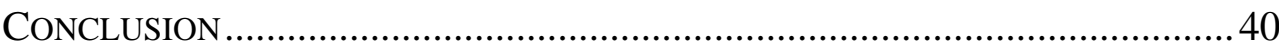

\section{INTRODUCTION}

Law developments in the last two decades, particularly the criminal law against human rights violations, get a reaction in various countries. The reaction of the criminal law against human rights violations, resulting Indonesian government looks like pay less attention towards human rights violations, especially with the case of East Timor, the Free Acheh Movement ${ }^{1}$ in Acheh, also in the case of Tanjung Priok. The reaction of the international community that wants the international criminal law on crimes against humanity was applicable in those cases. ${ }^{2}$

Rome Statute of the International Criminal Court has been agreed on July 15, 1998 and it has been 12 years exactly to the Rome Statute entered into force on July 1, 2002. But until now Indonesia is not a party who ratifies the Rome Statute. In the National Action Plan for Human Rights $\left(\right.$ RANHAM) ${ }^{3}$ from 2004 to 2009, the government expects to ratify the Rome Statute in 2008. In fact, the target of the plan of RANHAM has not been realized, thus in 2009-2014 the government pursues to ratify the Rome Statute in 2013.

In the meeting of the Working Group on the Universal Periodic Review which is a program of the United Nations Human Rights Council, Indonesia encouraged to ratify the Rome Statute of the International Criminal Court in the legislation. ${ }^{4}$

Even on the day of International Justice, which falls on July 17 that was celebrated by the National Commission on Human Rights together with the Indonesian Civil Society Coalition for the International Criminal Court,

\footnotetext{
${ }^{1}$ The Free Acheh Movement or Gerakan Acheh Merdeka or simply GAMwas a separatist group seeking independence for the Acheh Province of Sumatra from Indonesia.

${ }^{2}$ Harifin A. Tumpa, Peluang dan Tantangan Eksistensi Pengadilan HAM di Indonesia 1 (Jakarta. Kencana Prenada Media Grup 2010).

${ }^{3}$ The National Action Plan for Human Rights (RANHAM) aims to promote respect, promotion, fulfillment, protection and enforcement of human rights in Indonesia, taking into account the religious values, morals, customs, culture, and security, and order in Indonesia.

${ }^{4}$ Article of "Ratification of Rome Statute to Strengthen the Human Rights Protection in Indonesia" delivered by M. Akil Mochtaras Keynote Speaker at theNational Seminar on World Day of International Justice organized by the Indonesian Civil Society Coalition for the International Criminal Courtin collaboration with the Coalition for the International Criminal Court (CICC) and theNational Commission on Human Rights in Jakarta, Tuesday, July 17, 2012.
} 
they were demanding the ratification of the Rome Statute and encouraging the implementation of the National Action Plan for Human Rights (RANHAM) 2011-2014. ${ }^{5}$

The Rome Statute of the International Criminal Court establishes a permanent court to prosecute individuals who have committed atrocity crimes such as torture, genocide, and crimes of war $^{6}$, to ratify the Rome Statute of means subjecting to the jurisdiction of the International Criminal Court. However, naturally it is not subjecting ourselves absolutely, but rather complementary. That is, the international criminal court has authority if only the national legal system of a country is unwilling or unable to prosecute a case.

In the Article 17 paragraphs (2) and (3), the Statute has set the size of the unwillingness or inability of the national courts in prosecuting a case that should be taken over by the International Criminal Court. The criteria to determine the inability are: ${ }^{7}$

a. Judicial process that has been or is being done or decided aimed at protecting the perpetrators of criminal responsibility;

b. There was the delay in the judicial process that reason cannot be justified;

c. The judicial process is not carried out an independent and impartial manner.

Furthermore, the characteristic to determine the inability in certain cases, namely when International Criminal Court (ICC) considers that there has been a failure as a whole or a substantial or absence of a national court system to find the suspect or evidence and testimony or unable to conduct the judicial process. ${ }^{8}$

Despite of the complementary, the issue of ICC jurisdiction is being a big obstacle in the implementation of court performance. Even at the beginning of the preparation of the Rome Statute, the United States disagrees to sign the Rome Statute, one of which is the implementation of an international criminal court jurisdiction over criminal offenses committed (universal jurisdiction-delicta quasi-juris gentium). United States at the time was argued that the jurisdiction of the International Criminal Court

\footnotetext{
${ }^{5}$ http://news.liputan6.com/read/642189/komnas-ham-desak-pemerintah-segera-ratifikasi-statuta-roma (last visited Dec. 12, 2013 at 10:41 am).

${ }^{6}$ Sydney McKenney, The United States' Need to Ratify the Rome Statute, E-IR: E-INTERNATIONAL RELATION JOURNAL (Newcastle University, May 2013).

${ }^{7}$ Muladi, Statuta Roma Tahun 1998 TENTANG MaHKamah Pidana InTERnasional dalam

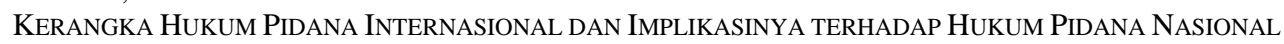
30 (Bandung: PT. Alumni 2011).

${ }^{8}$ Ibid.
} 
should apply only to criminals who are nationals of countries that ratified the Rome Statute (active personality jurisdiction). The above debate, adopted the provisions of the Rome Statute which are considered as a middle of the arguing road. Article 12 paragraph (2) of the Rome Statute provides that the jurisdiction of the International Criminal Court covering the area where the criminal act occurred (ratione loci) and criminal citizens of countries that ratified the Rome Statute (ratione personae).

The International Criminal Court has jurisdiction over four categories of international crimes namely genocide, crimes against humanity, war crimes and the crime of aggression. In both, the preamble to the Statute and Article 5, there is variously described as "the most serious crimes of concern to the international community as a whole". Elsewhere, the Statute describes them as unimaginable atrocities that deeply shock the conscience of humanity (Preamble), international crimes (Preamble) and "the most serious crimes of international concern" (Article 1$){ }^{9}$

Although Indonesia has not ratified the Rome Statute, but in solving the human rights violations that occurred in the past, Indonesian Human Rights Court formed in $\mathrm{Ad}$ hoc and has the authority to hear cases retroactively. Enactment of Law No. 26 of 2000 became the legal basis for the establishment of human rights in Indonesia. Article 1 point (3) determines that the reference to the Court of Human Rights or the Human Rights Court is a special court against human rights violations. ${ }^{10}$

\section{IMPLEMENTATION OF ROME STATUTE OF THE INTERNATIONAL CRIMINAL COURT TOWARDS REPUBLIC OF INDONESIA}

\section{A. Overview of the History of Indonesia: East Timor Tribunal}

Ad hoc court to proceed human rights case in East Timor, known as East Timor Tribunal was established to proceed the serious crimes for who were suspected committing that serious crimes in East Timor since April to September 1999. The tribunal was established by United Nations through the United Nations Transitional Administration in East Timor (UNTAET). ${ }^{11}$

East Timor was a Portuguese colony for hundreds of years and since 1960 has declared as a non-self-governing territory of Indonesia. In

\footnotetext{
${ }^{9}$ William A. Schabas, An InTroduction to the InTERnAtional Criminal Court 88 (Fourth Edition. Cambridge: Cambridge University Press 2011).

${ }^{10}$ Wiyono, Pengadilan Hak Asasi MANusia di Indonesia 75 (Jakarta: Kencana Prenada Media Grup 2013).

${ }^{11}$ UNTAET was established through Security Council Resolution No. 1272 in 1999.
} 
December $1975^{12}$, East Timor was claimed by Indonesia into the 27th province. Indonesian military invaded East Timor and on July 17, 1997, and as a consequence of the invasion, many victims at that time and a lot of people were suspected committing serious human rights violations. ${ }^{13}$ East Timor remains insecure and an opposition movement against Indonesia continues to grow as a consequence of the invasion. ${ }^{14}$

Finally, on August 30, 1999, 78.5\% of the population of East Timor refused to stay under Indonesian citizenship. After the announcement of the general election results, the East Timorese armed militia supported by Indonesian Armed Forces, suspected of committing violence throughout the territory of East Timor that led to the loss of lives, mass rape, chaos, and looting accompanied by the expulsion of citizens. ${ }^{15}$

Since the conflict on October 25, 1999, the United Nations took over the administration territory of East Timor. United Nations establish Temporary Administration of East Timor (United Nations Transitional Administration in East Timor, known as UNTAET). UNTAET was given the duty to carry out all of the affairs of legislative, executive, and judicial in East Timor, including the administration of justice, security, law enforcement, and the establishment of a new government that was effective. $^{16}$

The objective of UNTAET is to give support and aid to the new government in recovering the situation and condition to be more conducive. In 2000, UNTAET established the ad hoc court in order to prosecute alleged human rights violations that occurred in East Timor (The Special Panels of the Dili District Court). This ad hoc court could be regarded as an international judicial institution adopted in national legal system of Indonesia. $^{17}$

It was not easy to investigate, defend and prosecute the international crimes, especially if it is done with due process of law that gives full respect to the rights of suspects and defendants and focusing on those who hold the greatest responsibility. However, the court considered a failure in carrying out its mission. The criminal procedure law that specifically adopted by the

\footnotetext{
${ }^{12}$ In 1960, UN General Assembly declared East Timor as non-governance territory under Portugees Administrative Governance.

${ }^{13}$ UN Security Councils gave two resolutions, ordered Indonesia to withdraw its troops from the territory of East Timor and urges all States to respect the sovereignity of Timor Leste include of respecting the right of citizen to decide their own choice.

${ }^{14}$ Aristo M. A. Pangaribuan, Perdebatan Menuju Mahkamah Pidana Internasional 87 (Jakarta.

Badan Penerbit FHUI 2013).

${ }^{15}$ Ibid.

${ }^{16} \mathrm{Ibid}$, at 87 .

${ }^{17}$ Ibid.
} 
court cannot carry its function properly due to the lack of cooperation of law enforcement in Indonesia.

Ad hoc litigation is not running in line with the national judicial process. The inconsistencies regarding on the occurrence led to the law cannot prosecute the names whom allied with the alleged crime of human rights. In addition, national courts are unable to hear the main actors of the offences in East Timor. Many investigations cannot be proceeded because of the constraints of cooperation with the Indonesian government.

Many people thought that the enforcement of international law in Indonesia was not fully conducted in its Ad hoc court. A concrete example, Indonesian law enforcement cannot run a mission to drag the name who allegedly involved. In 2004, the crimes special units issued an Arrest Warrant Letter for Wiranto, a former commander of the Armed Forces ${ }^{18}$. Wiranto was considered as a person who had the responsibility for East Timor case. However, the warrant can never be implemented due to the refusal of the Indonesian government. The court run until 2006, and issued 400 prosecutions, but in reality, it was only 55 of the 400 prosecutions that successfully be prosecuted. ${ }^{19}$

Learning from the experience of Indonesian history in East Timor, there are several things that need to be reformed. Thus, if that history is repeated in the future while Indonesia has adopted the Rome Statute, the ICC could take over the case since the presumption that the aim of legal process is to protect the suspect, and the judicial before had not conducted independently or impartially as stated on Article 20 of the Rome Statute ${ }^{20}$. In a brief, Indonesian Civil Society Coalition for the International Court ${ }^{21}$ stated that ratification of Rome Statute will become a measurement for the seriousness of Indonesia in upholding international justice regime and stopping impunity. ${ }^{22}$

\footnotetext{
18 “Arrest Warrant for Jakarta General” see at: http://news.bbc.co.uk/2/hi/asia-pacific/3699879.stm (last visited Saturday, March 15, 2014 at 4:04 pm).

${ }^{19}$ Harifin A Tumpa, Op.cit., at 166.

${ }^{20}$ Rome Statute of the International Criminal Court Article 20 (5): "Otherwise were not conducted independently or impartially in accordance with the norms of due process recognized by International law and were conducted in a manner which, in the circumtances, was inconsistent with an intent to bring the person concerned to justice".

${ }^{21}$ Indonesian Civil Society Coalition for the International Criminal Court is a group of civil society organizations that compaigns for the ratification and implementation of the Rome Statute on the International Criminal Court, established in Jakarta in 2006.

${ }^{22}$ Progress Report. Indonesia Efforts to Ratify the 1998 Rome Statute of the International Criminal Court. presented at a Diplomatic Briefing in Jakarta, December 14, 2012. Download at http://www.elsam.or.id/downloads/1353296803_Indonesian_progress_report_CICC_Nov_2012.pdf (last visited Thursday, April 10, 2014 at 5:59 pm).
} 
B. Indonesia's Role in the Establishment of the International Criminal Court

During the process of the adoption of the Rome Statute, Indonesia was actively involved by sending the delegates to participate in the Diplomatic Conference in Rome in July, 1998, in which the Rome Statute was adopted. In that historical moment, Indonesia addressed its support to the adoption of the Rome Statute and the establishment of the International Criminal Court. Indonesia also articulated its intention to ratify the Statute. ${ }^{23}$

In 1999, Indonesia delivered a statement in UN General Assembly regarding on Indonesia's view of the Statute. Indonesia, through the Ministry of Justice, firmly stated that: "universal participation should become the spear point of the ICC" and also stated that: "the Court becomes the results of a cooperation of all nations regardless of political, economic, social, and cultural differences". Indonesia also stated that the Rome Statute gives a more important meaning to the values contained in the UN Charter, which includes agreement, impartiality, non-discrimination, state sovereignty, and territorial integrity. Indonesia emphasized that the court should attempt to be complement, but not a replacement, to national law mechanism. ${ }^{24}$

The government stated that the review was conceded to the Rome Statute in order to consider several things, particularly effective mechanism for disseminating its content also its implementation. Since Indonesian citizens who spread across 13,000 islands and the government obliged to educate their citizens on the establishment of a new institution which aimed to enforce the law effectively. ${ }^{25}$

In order to achieve the objectives, in 2004, the President of Indonesia, Megawati Sukarnoputri passed a National Human Rights Action Plan through Presidential Decree of 2004. Specifically, the decree stated that Indonesia intended to ratify the Rome Statute in 2008. In order to follow the plan, the President established National Ratification Committee to arrange all of the matters relating to the ratification process. ${ }^{26}$

On several occasions, the government has also stated that a national legislation needs to be formulated for the purpose of cooperation with the court before the ratification is conducted. Furthermore, there should be an amendment to the national law in order to create the synergy with the Rome Statute. Unfortunately, the planning to ratify the Rome Statute in 2008

\footnotetext{
${ }^{23}$ Indonesia toward the Ratification of the Rome Statute, Working Paper of Indonesian Civil Society Coalition for the International Criminal Court, at 2.

${ }^{24} \mathrm{Ibid}$, at 3.

${ }^{25}$ Ibid.

${ }^{26}$ Ibid.
} 
through Presidential Decree of 2004 was delayed because of political reasons that general election in 2009. After failing to execute the decree, the government rescheduled their commitment to a decree issued in 2011, therefore Indonesia will ratify the Rome Statute in $2013 .^{27}$

By ratifying Rome Statute of the International Criminal Court, many people hoped that Indonesia could become a model of law enforcement on human rights violations in international community. Indonesia as the fourth state with the largest population in the world regulated the human rights issue in the 1945 Constitution as the highest law of Indonesia. Amnesti Internasional $^{28}$, stated that ratification of Indonesia as one of the largest and most populated country, will greatly help to promote universal ratification of the Rome Statute in the world. ${ }^{29}$

\section{The Process of Indonesia in Ratifying the Rome Statute}

Respecting the human rights has become a mandate of the 1945 Constitution. During amendments of the Constitution in 1999 to 2002, the number of rules regarding on human rights as stated in Universal Declaration of Human Rights included into the second amendment of the 1945 Constitution in August 2000. In addition, in 1999 the Government of Indonesia enacted a special law governing human rights through Law No. 39 of $1999 .^{30}$

Indonesia had ratified the International Covenant on Civil and Political Rights (ICCPR) on October 28, 2005, which clearly states the protection of fundamental freedoms, including the right to a fair trial. Since the fall of the Suharto regime in 1998, there are many important reforms in the field of human rights, including the 1945 amendments in 1991 to 2002 and the ratification of human rights instruments. ${ }^{31}$

Based on the Constitution, it is the obligation of the State to eliminate human rights violations. ${ }^{32}$ The emergence of the ICC is a tool to achieve the universal humanism and social justice also participated actively in the drafting process of the Rome Statute. Initially, the Indonesian government also plans to conduct the ratification of the Rome Statute in 2008 but it was rescheduled into 2013. Yet, the Statute also is not going to be ratified until 2014 . $^{33}$

\footnotetext{
${ }^{27}$ Aristo M. A. Pangaribuan, op.cit., at 79.

${ }^{28}$ A Non-Governmental Organization which concerns to human rights issue in Indonesia.

${ }^{29}$ Aristo M. A. Pangaribuan, op.cit., at 79.

${ }^{30}$ Aristo M. A. Pangaribuan, Op.cit., at 93.

31 Ibid.

${ }^{32}$ Preamble of Indonesian Constitution 1945.

${ }^{33}$ Aristo M. A. Pangaribuan, Op.cit., at 93.
} 
Some countries are resistant to the existence of the ICC because of the power owned by the ICC opened up opportunities for the inclusion of political influences ${ }^{34}$. Furthermore, the nature of the Rome Statute is not similar with other international agreements. Because of this consideration, the government conducted the postponement on implementation of the decree to ratify the ICC. ${ }^{35}$

The government under President Susilo Bambang Yudhoyono then scheduled a commitment to ratification by issuing Presidential Decree No. 23 of 2011 regarding on National Plan of Human Rights which states that Indonesia will conduct the ratification of the Rome Statute in 2013. The President also established a new National Ratification Committee to implement the plan. The committee is composed of appointed officials of the Ministry of Foreign Affairs, Ministry of Law and Human Rights, Indonesian National Police, Attorney General's Office, Ministry of Defence, Ministry of Social Affairs and the Indonesian Military. ${ }^{36}$

Finally, in March 2013, a delegation led by the Ministry of Law and Human Rights visited the headquarters of the ICC in the Hague, to discuss the process of ratification of the Rome Statute. It was only raised general issues such as the retroactive and the elements of a crime in the Rome Statute that would be adopted by national legislation. Legal procedural issues were not addressed specifically. ${ }^{37}$

In fact, the issue of procedural and legal events is important in order to its practice, the basic principle of complementarity of the ICC which emphasizes the sovereignty of the State can be effective. Because of the Rome Statute into force, the obligation to carry out the mandate of the Rome Statute for the Indonesian arises. Through the Rome Statute, the ICC and Indonesia are both a duty to enforce justice to the serious crimes of human rights. ${ }^{38}$

\section{A Brief Comparison Between Rome Statute of the International Criminal Court and Indonesian Criminal Procedure Code}

Legal procedure of Rome Statute is a model of modern criminal procedure code because it is created from the consensus of participating countries who discuss the establishment of a universal system of criminal

\footnotetext{
${ }^{34}$ Lu Jianping and Wang Zhixiang, ICC and Non-Party States: China's Attitude towards the ICC, 3 OXFORD JOURNAL OF INTERNATIONAL CRIMINAL JUSTICE 608 (2005).

${ }^{35}$ Aristo M.A. Pangaribuan, Op.cit., at 94.

${ }^{36}$ Ibid.

${ }^{37}$ Ibid.

${ }^{38}$ Ibid.
} 
procedure. Criminal procedure in the Rome Statute can be said as a combination of two systems of criminal procedure law, those are the adversarial system ${ }^{39}$ which adopted by the common law states and inquisitorial system ${ }^{40}$ which adopted by the civil law countries, including Indonesia. ${ }^{41}$

The easiest way to distinguish between inquisitorial and adversarial systems is the role of the judge who prosecuted the case. Where in the inquisitorial system, the judge is also active because the goal is to find the material truth, while in the adversarial system the judge is passive, because the court was an encounter between lawyers and the prosecutors. ${ }^{42}$

\section{The Process of Investigation}

The Rome Statute does not distinguish between the process of investigation as regulated in the Indonesian Criminal Code which divided into two steps, known as "penyelidikan" and "penyidikan". The Rome Statute only uses the terminology of investigation or inquiry in pre-trial process, while confirmation of charges if the investigation into the case has been completed and taken to a pre-trial hearing for confirmation before heading to the trial chamber. ${ }^{43}$

The prosecutor has both duties and powers with respect to an investigation $^{44}$. He is required to cover all facts and evidence relevant to an assessment of whether there is criminal responsibility under the Statute, and doing so, investigate incriminating and exonerating circumstances equally ${ }^{45}$. The wording suggests a prosecutor with a high level of neutrality and impartiality.

\footnotetext{
${ }^{39}$ The legal system in the United States is known as an adversary system. In this system, the parties to a controversy develop and present their arguments, gather and submit evidence, call and question witnesses, and, within the confines of certain rules, control the process. The fact finder, usually a judge or jury, remains neutral and passive throughout the proceeding. See at http://legal-dictionary. thefreedictionary.com/Adversary+System (last visited Thursday, April 10, 2014 at 5:40 pm).

${ }^{40}$ The inquisitorial system can be defined by comparison with the adversarial, or accusatorial, system used in the United States and Great Britain. In the Adversary System, two or more opposing parties gather evidence and present the evidence, and their arguments, to a judge or jury. The judge or jury knows nothing of the litigation until the parties present their cases to the decision maker. The defendant in a criminal trial is not required to testify. See at http://legaldictionary.thefreedictionary.com/inquisitorial+system (last visited Thursday, April 10, 2014 at 5:43 pm).

${ }^{41}$ Aristo M. A. Pangaribuan, Op.cit., at 114.

${ }^{42} \mathrm{Ibid}$, at 115.

${ }^{43}$ Ibid.

${ }^{44}$ Rome Statute of the International Criminal Court, Article 54: Duties and powers of the Prosecutor with respect to investigations.

${ }^{45}$ Ibid, Art. 54 (1).

${ }^{46}$ William A. Schabas, op.cit., at 261.
} 


\section{Pretrial Chamber}

In Rome Statute, pre-trial hearing conducted by the pretrial chamber which is needed to confirm the ICC indictment, to determine whether a case has been conducted by the investigative stage of the prosecution can be brought to court (trial chamber) or yet. ICC pretrial Assembly consists of at least six judges, who are divided into chambers (Pretrial Chamber I, II, and III), which have a supervisory function of the different cases of each. ${ }^{47}$

The main aim of the pre-trial chamber is to do a check and balance of power held by the ICC prosecutor. The supervision of pretrial chamber is expected to run the investigative process in objective way and free of political purposes. Pretrial chamber formation in the Rome Statute is the combination between the two legal systems, which are inquisitorial and adversarial system. Furthermore, the ICC prosecutor is given the freedom and power to conduct investigations and on the other hand, the role and authority of the prosecutor are counterpoised by the presence of pretrial chamber. ${ }^{48}$

\section{Evidence}

Unlike the common law system, with its complex and technical rules of evidence, the Statute follows the tradition of international criminal tribunals by allowing the admission of all relevant and necessary evidence. Probably the biggest surprise here, for lawyers trained in common law systems, is that there is no general rule excluding hearsay or indirect evidence, although it seems that in ruling on the admissibility of such evidence, the court will be guided by hearsay exceptions generally recognized by some national legal system, as well as the truthfulness, voluntariness and trustworthiness of the evidence, as appropriate. As Helen Brady has explained, debates in the Ad hoc Committee and the preparatory committee revealed a deep chasm between the civil law and the common law traditions on the scope and nature of the ICC's rules of evidence. However, a compromise was finally attained a delicate combination of civil and common law concepts of fair trial and due process. ${ }^{49}$ To be admissible, evidence must be relevant and necessary. $^{50}$

\footnotetext{
${ }^{47}$ Aristo M. A. Pangaribuan, op.cit., at 117.

${ }^{48}$ Ibid., at 117.

${ }^{49}$ William A. Schabas, Op.cit., at 312.

${ }^{50}$ Rome Statute, Art. 69 (3): The parties may submit evidence relevant to the case, in accordance with aricle 64 . The court shall have the authority to request the submission of all evidence that it considers necessary for the determination of truth.
} 


\section{Trial}

Although much of the procedure of the court is a hybrid of different judicial system, it seems clear that there is a definite title towards the common law approach of an adversarial trial hearing. However, the exact colouring that the court may take will ultimately be determined by the judges. The terms of the Statute are larger enough to provide for considerable divergence in judicial approaches. ${ }^{51}$

The trial shall be held in public, something that is expressed both as a duty of the trial chamber and as a right of the accused. Pretrial Chamber I has explained that "the legal regime of the ICC presumes the public nature of court proceedings and documents". Nevertheless, the Trial Chamber may depart from the general principle of a public hearing. Visitors to the Court are often taken back by how little they can actually see the proceedings. Often, the sessions are closed to the public entirely; other limitations are also frequent, such as witnesses testifying behind screens. A detailed enumeration of exceptions to the public hearing principle had been proposed but was rejected by the Preparatory Committee. ${ }^{52}$

Limitations on the public nature of the proceedings are also justified in order to protect confidential or sensitive information. There may also be claims to confidentiality based on privilege. But the major source of the problems with this exception will be information derived from sovereign States. ${ }^{53}$ The Statute allows a State to apply "for necessary measures" to respect "confidential or sensitive information". ${ }^{4}$

The accused must be present at trial, even those parts of it that are held in camera. ${ }^{55}$ During the drafting of the statute, there was a considerable debate about whether or not to permit in absentia trials, which are widely held under the continental procedural model. It was argued that in absentia trials were particularly important in the context of international justice because of the didactic effect as well as the extreme practical difficulties involved in compelling attendance at trial. The right of the accused to be present at trial is recognized in the principal international human rights instruments, ${ }^{56}$ but international tribunals and monitoring bodies have not

\footnotetext{
${ }^{51}$ William A. Schabas, Op.cit., at 302.

${ }^{52}$ Ibid, at 303.

${ }^{53} \mathrm{Ibid}$, at 304.

${ }^{54}$ Rome Statute, Art. 68(6): A State may make an application for necessary measures to be taken in respect of the protection of its servant or agents and the protection of confidential or sensitive information.

${ }^{55}$ Rome Statute, Art. 72(7): Allows for a hearing concerning the protection of national security information to take place ex parte, that is, in the absence of one or both of the parties.

${ }^{56}$ International Covenant on Civil and Political Rights.
} 
viewed presence at trial as indispensable. ${ }^{57}$

\section{Problem in Ratification of the Statute}

The process of establishment of the Rome Statute through a very long debate since the nature of the ICC has supranational powers to combat serious human rights crimes in the territory of its members. As a result, the implementation of the Rome Statute will also affect the jurisdiction of a State and threaten the sovereignity of its member states. ${ }^{58}$

There are concerns in some parties that by ratifying the Rome Statute of the International Criminal Court means approve and commit to all the rules in the Rome Statute. For some countries, it has a big risk, especially for developing countries, because of the presumption that the ICC would undermine the rule of law national authority of the ICC through the intervention of the legal system of a country. ${ }^{59}$

Fears of some people of international intervention by the ICC into the Indonesian national laws are actually answered by the description of the principle of complementary which is a fundamental principle of the applicability of the ICC in a State. This principle is stated in paragraph 10 of the Preamble which means that the ICC is a complementary means, if national courts are unwilling or unable to adjudicate a grave violation of human being dismissed concerns that the basic reason for the State to international intervention in the country's sovereignty when becoming the member state.

Article 1 of the Rome Statute also states that the purpose of the establishment of the Court is to apply criminal jurisdiction over international as contained in the Statute and has the function to complete national judicial system of the State. ${ }^{60}$ Article 1 of the Rome Statute also states that the purpose of the establishment of the Court is to apply criminal jurisdiction over international as contained in the Statute and has the function to complete the national judicial system of the State. ${ }^{61}$

Exposure above clearly illustrates that the ICC does not serve to replace national courts of a contracting State, the obligation to implement the punishment of perpetrators of crimes included in the jurisdiction of the

\footnotetext{
${ }^{57}$ William A. Schabas, Op.cit., at 305.

${ }^{58}$ Aristo M. A. Pangaribuan, Op.cit., at 33.

${ }^{59}$ Indonesian Civil Society Coalition for the International Criminal Court, Jalan Panjang Menuju Ratifikasi ICC di Indonesia, at 125. Download at http://docs.perpustakaanelsam.or.id/icc/files/fileMR.02.pdf (last visited Tuesday, April 8, 2014 at 2:26 pm).

${ }^{60}$ Ibid.

${ }^{61}$ Indonesian Civil Society Coalition for the International Criminal Court, op.cit., at 127.
} 
ICC. That the primary responsibility to punish perpetrators of crimes is the jurisdiction of the ICC is the State, not the ICC, because of the mechanism of law enforcement in the State to be really effective, for example by inserting a crime within the jurisdiction of the ICC as crimes under national law system. ${ }^{62}$

Efforts to gain common understanding on the ratification have been ongoing. In November 2011, the Coordinating Ministry on Politics, Laws and Security initiated a discussion on the ratification plan, and it was attended by representatives from the Ministry of Foreign Affairs, the Ministry of Law and Human Rights, the Ministry of Defence and also some legal scholars. The meeting concluded, among others: ${ }^{63}$

(1) That the Rome Statute of the International Criminal Court was established as a result of international community's commitment to enhance peace, security and public order, it signifies moral responsibility of every state to prosecute crimes against humanity, to enforce human rights and to uphold justice as well as to prevent impunity;

(2) That ratification of the Rome Statute requires a background research and academic paper, in order to have common understanding regarding the material and judicial consequences of the Statute. This academic paper would then need to be discussed with relevant stakeholders and the public to gather their inputs and to address valid concerns from the public;

(3) Since there are still different interpretations on certain articles in the Statute and its judicial consequences, joint measures would be necessary to address it, in particular on issues related to sovereignty and the judiciaries;

(4) There are two different perspectives regarding the timing of ratification. One side believes that it is now the time for ratification and this is supported by, among others, the Ministry of Foreign Affairs, the Ministry of Law and Human Rights, while the Ministry of Defence, the Indonesian National Defence Forces and a number of Indonesian international criminal law experts believe that now is not the time for ratification;

(5) Politically speaking, Indonesia received a lot of pressure from the international community to ratify the Statute. Ratification will also facilitate the establishment of a "tribunal", yet we cannot neglect international practices and how this might compromise Indonesia's "bargaining position"

\footnotetext{
${ }^{62}$ Ibid.

${ }^{63}$ Progress Report Indonesia Efforts to Ratify the 1998 Rome Statute. Prepared by: Indonesian Civil Society Coalition for the International Criminal Court November 2012. See at http://www.elsam.or.id/downloads/1353296803_Indonesian_progress_report_CICC_Nov_2012.pdf (last visited Friday, April 11, 2014 at 3:37 pm).
} 
since ratification is related to international human rights enforcement, trade and economy;

(6) There should be a clear arrangement in the domestic law regarding the procedure to implement the Statute, mandate and authorities of different institutions, etc.

In December 2011, the former Chair of Constitutional Court, Justice Mahfud MD, conveyed his support for ratification. He advised the Government of Indonesia to immediately ratify the Statute since it could serve as an instrument to address cases of gross human rights violations in the future. Mahfud also added that Indonesia should be able to anticipate the possibility of human rights violations in the future and how international society might interfere. Mahfud said that Indonesia need not to worry that ratification will infringe its jurisdiction, because if no extraordinary violations happened and Indonesia will not request for the Court to interfere, thus the Statute will not be enforced. Mahfud recommended the government and the parliament to seriously discuss the idea of ratification. ${ }^{64}$

\section{THE IMPORTANCE OF THE RATIFICATION OF THE ROME STATUTE}

An imperative to ratify the Rome Statute in 2008 is not only because of the normative reason that it has been mentioned in RANHAM 2004-2009. Ratification of the Statute will give a very positive contribution to the enforcement and protection of human rights in Indonesia as well as to peace in the region and in the world. Besides, it will also make Indonesia seen as equal to the other nations in the world who have committed themselves earlier to the order of international justice. ${ }^{65}$

In detail, the importance and advantages of ratification of the Rome Statute are explained as follows:

(1) Abolishing Various Practices of Impunity

Ratification of the Rome Statute is urgently needed by Indonesia, moreover after we have seen examples of treatments to the cases of serious human rights violations taking place in Indonesia, which end up with the failure of the Court to find and publish "the most responsible persons".

The establishment of the International Criminal Court is aimed at shopping and preventing practices of impunity toward perpetrators of serious international crimes, which is regulated by the Rome Statute, and is aimed at making a significant change to behaviors of nation-state actors.

\footnotetext{
${ }^{64} \mathrm{Ibid}$, at 7.

${ }^{65}$ Indonesia towards the Ratification of the Rome Statute, Working Paper of Indonesian Civil Society Coalition for the International Criminal Court. Op.cit., at 10.
} 
Such crimes representation of the sovereignties of their countries, in other words, there are three important things due to the existence of the International Criminal Court as a preventative from serious international crimes to happen, as regulated in the Rome Statute. ${ }^{66}$

First, those in state power will no longer be able to do any practice of impunity by any reason aimed at protecting crime perpetrators by using national law mechanism, either by arranging the court-session, which is aimed at protecting the perpetrators, or by amnesty.

Second, it has something to do with the very far reach of the International Criminal Court in applying its jurisdiction, even though its presence is complementary. Besides, perpetrators cannot seek protection in national legislation mechanisms of their own countries, they cannot seek protection in other countries either, even if the countries are not parties of the Statute.

Third, particularly for countries which send peace keeping force, the International Criminal Court even protects personnel of peace keeping force from possibilities of acts which are categorized serious international crimes, and not on the contrary threaten the existence of peace keeping force that is doing their operation in a conflict area. In other words, the International Criminal Court provides legal protection for personnel of peace keeping force. $^{67}$

Based on the explanation above, ratifying the Rome Statute will mean that Indonesia will be bound by a strong commitment to provide protection of human rights for its citizens, and will be bound to do the obligation to punish perpetrators of serious international crimes in proper way in order not to be seen as "unwilling" country. ${ }^{68}$

(2) Overcoming Weaknesses of Indonesia's Legal System

Bringing perpetrators of international crimes to the court and punishing them are forms of state responsibility and manifestation of the protection of human rights provided by the State to its citizen. To implement the responsibility, however, Indonesia is often hindered by various weaknesses and insufficiency of its existing legal system. ${ }^{69}$

Ratifying the Rome statute will become an impulse for Indonesia to immediately overcome its shortcomings. Besides, ratification of the Rome Statute containing rules about forms of extraordinary crimes, which are dynamic, but are not regulated in Indonesian Criminal Code, can motivate

\footnotetext{
${ }^{66}$ Ibid.

${ }^{67}$ Ibid.

${ }^{68}$ Ibid.

${ }^{69} \mathrm{Ibid}$, at 13.
} 
the State to improve its judicial system, including the Criminal Code Procedure. This is by consideration that after ratifying the Statute, a party state must have rules of implementation which work in accordance with contents of the Statute, and its national law must be able to provide a guarantee for full cooperation with the International Criminal Court. ${ }^{70}$

(3) Protection for Witnesses and Victims

Process of ratifying the Rome Statute is an effort to prevent reoccurance of crimes with greater effects in the future, and also to give protection and reparation for the victims. Besides carrying out punishment for the perpetrators, giving compensations to the victims is one form of state responsibility when a serious human rights violation is taking place in its territory. ${ }^{71}$

Protection for victims of serious human rights violations in Indonesia is regulated in Article 34 of Law No. 26 of 2000 on Human Rights Court, and followed by Government's Regulation No. 2 of 2002 concerning protection for witnesses and victims as its rule of implementation. However, when compared to the Rome Statute, many rules contained in the Statute are not accommodated in the regulation. For instance, the existence of trust fund for the sake of witnesses and victims, which is collected from fine or ransom, of which the arrangement is delegated to the Assembly of Party States. ${ }^{72}$

\section{A. Important Steps on Rome Statute of the ICC Ratification}

It is commonly known that there is a doubt on politics of the Indonesian government to ratify the ICC because of its supra national and feared would tear apart the rule of law in Indonesia. This is the main reason why the existence of the ICC faces many challenges in Indonesia even from the government itself. $^{73}$ The unwillingness of the government to be a member of the ICC showed by the ratification of the Rome Statute is going improbability until now, which has actually been planned since 2004. The last visit of Indonesian government delegation in March 2013 to the ICC headquarters in Den Haag, Netherlands caused ratification plan was surfaced again. ${ }^{74}$

But on the other hand, the ratification of the Rome Statute as mandated by Presidential Decree in 2004 is debatable to be realized. This is because

\footnotetext{
${ }^{70}$ Ibid.

${ }^{71}$ Ibid.

${ }^{72} \mathrm{Ibid}$

${ }^{73}$ http://news.detik.com/read/2013/03/08/045914/2189116/10/indonesia-belum-tepat-ratifikasistatuta-roma (last visited April 4, 2014 at 12:13 pm).

${ }^{74}$ Aristo M. A. Pangaribuan, op.cit., at 134.
} 
Indonesia will go through a process of general elections in 2014 that led to the regime change, and as a consequence, the political situation in Indonesia will reach its lowest point, therefore the government will reconsider to pull out the strategic policies that have a major impact, here is ratification of the Roma statute. In such situations, it is doubtful that the Indonesian government will stipulate a major decision such as the implementation of the ICC jurisdiction. ${ }^{75}$

In implementing its commitment to ratify the Rome Statute, the thing that must be considered is the compatibility of Indonesian Law to the Rome Statute. The main priority of the Indonesian government is to ensure that Indonesian law can effectively support the implementation of the ICC at the national level if the jurisdiction of the ICC is being practiced in Indonesia. Obviously, we do not expect it to be, which in Indonesian occurred the cases of human rights violations. However, these preparations are still needed, given the consequences of a state to be a member of the ICC has a big responsibility towards human rights commitments. With the purpose of legal conflict between the laws of the Rome Statute and national law can be avoided. $^{76}$

The practice of compatibility between the Rome Statute and national law conducted by almost all of the countries since the members of Rome statute given a big responsibility when these countries become part of the Rome Statute. The Indonesian government should be fully aware, that by being a part of the ICC, the old conception of the absolute sovereignty as described by Thomas Hobbes in Leviathan. ${ }^{77}$ The conception of absolute sovereignty is becoming out-of-date and shifted along with the development of civilization, and the ICC was even more reinforced sovereignty by giving the responsibility to the state to struggle the crimes against human rights. That's the consequence of the Indonesian government which must be fulfilled, if Indonesia becomes a member of the ICC. ${ }^{78}$

In the context of the interaction between the States by the ICC, the State shall implement and support ICC procedures, provided if it does not arise conflict with the international obligations of the State. Because of the commitment to implement the enforcement of human rights, the ICC will depend heavily on the process of interaction with member States. Therefore, the specific national legal system should support the process of interaction

\footnotetext{
${ }^{75}$ Ibid, at 135 .

${ }^{76}$ Ibid.

${ }^{77}$ http://www.gutenberg.org/files/3207/3207-h/3207-h.htm (last visited Monday, April 7, 2014 at 5:45 $\mathrm{pm})$.

${ }^{78}$ Aristo M. A. Pangaribuan, op.cit., at 135.
} 
with an amendment and revision of the existing regulations. ${ }^{79}$

\section{B. Recommended Measures}

According to Aristo MA Pangaribuan, the best way to prepare the entrance of Indonesian ratification of the ICC is to conduct the process of synergy with the national law of the Rome Statute including the criminal law, criminal procedure law, extradition, human rights courts and the Human Rights Act itself, the ultimate goal of synergy are:

a. To embed the Rome Statute as an extension of the national judicial system.

b. To avoid potential conflicts between the ICC and the Indonesian State Law.

c. To make the internal legal procedures during the event for the Indonesian jurisdiction active in Indonesia. ${ }^{80}$

There are two ways to realize the synergies between the Statute and Indonesian regulation. Firstly, it could be conducted by revising the existing regulations related to the statute as what has been conducted by other states as Australia, United Kingdom, Netherlands, and Germany. By conducting this step, the integration process of existing regulation in the Statute could run in a whole because the amendment is referred to the Statute and minimizes the conflict in the interpretation of Act. ${ }^{81}$

Secondly, it could be conducted by enacting a new act that definitely stated the cooperation between national law and the statute or commonly said as cooperation act that will describe some exceptions thru the regulations, especially related to the criminal procedure law which could arise the conflict with the Rome Statute. For example, the regulation about the principle of ne bis in idem, that could be allowed in enforcement of Statute and its definition is not referred to the other act excluding that cooperation act. The cooperation act also supposes to distinguish the procedures and flows of ICC trial and national trial. ${ }^{82}$

\section{CONCLUSION}

The ratification of the Statute is urgently needed since there is several human rights violation happened in Indonesia. The case of Trisakti and Semanggi I in 1998, Semanggi II and Tanjung Priok in 1999, and cases of

\footnotetext{
${ }^{79} \mathrm{Ibid}$

${ }^{80}$ Ibid, at 139 .

${ }^{81}$ Ibid.

${ }^{82} \mathrm{Ibid}$, at 141.
} 
serious human rights volation in Acheh during the implementation of Military Operation Area (Daerah Operasi Militer), also the cases of East Timor were ended up without finding the person who had to be responsible to those cases.

Initially, the ratification of the Rome Statute was scheduled for 2008, yet it has not been successful and it is being rescheduled for 2013-2014. There are some concerns that the second ratification plan will face many obstacles, particularly due to different views concerning the importance of ratification of the Rome Statute among government agencies. Meanwhile, there is a growing support from the public regarding on the plan to ratify the Statute.

Indonesia encouraged to ratify the Rome Statute of the International Criminal Court in the legislation as soon as possible. In ratifying the Statute, Indonesian government has to ensure that the Statute can interact well with Indonesian law which then creates a synergy to the implementation of the ICC in Indonesia. As a member of the Rome Statute, Indonesia has an obligation to cooperate with the ICC with the aim of Indonesia which becomes the absolute country that upholds human rights. 